\title{
RESEARCH
}

Open Access

\section{Reduced turnover rate of topsoil organic carbon in old-growth forests: a case study in subtropical China}

Xin Xiong ${ }^{1,2} \mathbb{B}_{\text {, Juxiu Liu }}^{1,2}$, Guoyi Zhou ${ }^{3}$, Qi Deng ${ }^{1,2}$, Huiling Zhang ${ }^{1,2}$, Guowei Chu ${ }^{1,2}$, Ze Meng ${ }^{1,2}$ and Deqiang Zhang ${ }^{1,2^{*}}$

\begin{abstract}
Background: Old-growth forests are irreplaceable with respect to climate change mitigation and have considerable carbon (C) sink potential in soils. However, the relationship between the soil organic carbon (SOC) turnover rate and forest development is poorly understood, which hinders our ability to assess the $C$ sequestration capacity of soil in old-growth forests.

Methods: In this study, we evaluated the SOC turnover rate by calculating the isotopic enrichment factor $\beta$ (defined as the slope of the regression between ${ }^{13} \mathrm{C}$ natural abundance and log-transformed $\mathrm{C}$ concentrations) along $0-30 \mathrm{~cm}$ soil profiles in three successional forests in subtropical China. A lower $\beta$ (steeper slope) is associated with a higher turnover rate. The three forests were a 60-year-old $P$. massoniana forest (PF), a 100-year-old coniferous and broadleaved mixed forest (MF), and a 400-year-old monsoon evergreen broadleaved forest (BF). We also analyzed the soil physicochemical properties in these forests to examine the dynamics of SOC turnover during forest succession and the main regulators.

Results: The $\beta$ value for the upper 30-cm soils in the BF was significantly $(p<0.05)$ higher than that in the PF, in addition to the SOC stock, although there were nonsignificant differences between the BF and MF. The $\beta$ value was significantly $(p<0.05)$ positively correlated with the soil recalcitrance index, total nitrogen, and available nitrogen contents but was significantly $(p<0.01)$ negatively correlated with soil $\mathrm{pH}$.

Conclusions: Our results demonstrate that SOC has lower turnover rates in old-growth forests, accompanied by higher soil chemical recalcitrance, nitrogen status, and lower soil pH. This finding helps to elucidate the mechanism underlying $C$ sequestration in old-growth forest soils, and emphasizes the important value of old-growth forests among global $\mathrm{C}$ sinks.
\end{abstract}

Keywords: Forest succession, Old-growth forests, Soil organic carbon, Turnover rate, ${ }^{13} \mathrm{C}$ natural abundance

\footnotetext{
* Correspondence: zhangdeq@scib.ac.cn

'Key Laboratory of Vegetation Restoration and Management of Degraded Ecosystem, South China Botanical Garden, Chinese Academy of Sciences, Guangzhou 510650, China

${ }^{2}$ Center for Plant Ecology, Core Botanical Gardens, Chinese Academy of Sciences, Guangzhou 510650, China

Full list of author information is available at the end of the article
}

\section{Springer Open}

(-) The Author(s). 2021 Open Access This article is licensed under a Creative Commons Attribution 4.0 International License, which permits use, sharing, adaptation, distribution and reproduction in any medium or format, as long as you give appropriate credit to the original author(s) and the source, provide a link to the Creative Commons licence, and indicate if changes were made. The images or other third party material in this article are included in the article's Creative Commons licence, unless indicated otherwise in a credit line to the material. If material is not included in the article's Creative Commons licence and your intended use is not permitted by statutory regulation or exceeds the permitted use, you will need to obtain permission directly from the copyright holder. To view a copy of this licence, visit http://creativecommons.org/licenses/by/4.0/. 


\section{Background}

Old-growth forests are considered the climax ecosystems (Clements 1916), and the age threshold varies from 100 to 500 years for different forest biomes (Jarvis 1989; Goulden et al. 2011; Liu et al. 2014). Increasing evidence shows that old-growth forests can continue to accumulate carbon (C) in soils (Zhou et al. 2006a; Luyssaert et al. 2008), contrary to the longstanding view that they are C neutral (Odum 1969; Jarvis 1989). However, the mechanism of the soil $\mathrm{C}$ sink in old-growth forests remains uncertain. Plant $C$ input and the soil organic carbon (SOC) turnover rate are commonly considered two key factors in determining the $\mathrm{C}$ sequestration capacity of soil (Paul 2016; Nyawira et al. 2017). The relationship between litter inputs and soil $\mathrm{C}$ storage has been well examined in forest C cycle studies (Huang et al. 2011; Tefs \& Gleixner 2012; Zhou et al. 2019), whereas the SOC turnover rate has become the dominant uncertainty in the $\mathrm{C}$ sequestration capacity of forest soils. Therefore, accurately quantifying the soil $\mathrm{C}$ turnover rate and its relationship with forest development is crucial to understanding the mechanisms of soil $\mathrm{C}$ sinks and predicting future $\mathrm{C}$ budget dynamics in the world's forests.

A recent study revealed that old-growth forest soils have higher organic $\mathrm{C}$ inputs than young forest soils, which was caused by the higher proportion of products transferred to the soil during the decomposition of highquality litter in old-growth forests (Xiong et al. 2020a). Considering the emerging view that high-quality litter inputs more easily form stable soil organic matter through microbial assimilation and mineral protection (Cotrufo et al. 2013; Xu et al. 2014), whether SOC has a longer residence time in older forests becomes an intriguing question. Forest succession is the coevolution of above- and belowground systems. A rich body of literature demonstrates changes in the microclimate (Sánchez-Reyes et al. 2020), tree composition and stand structure (Gray et al. 2016), plant productivity (Goulden et al. 2011), soil microbial diversity and function (Ren et al. 2019), soil nutrient availability (Lu et al. 2015), and soil physicochemical properties (Li et al. 2013) following forest succession. These variables inevitably exert direct and indirect impacts on the biogeochemical cycling of $\mathrm{C}$ in the soil, accompanied with the alteration of input and output processes (Sokołowska et al. 2020). It remains unclear, however, how the variables affect the turnover rate of SOC along forest succession.

As the current understanding of soil $\mathrm{C}$ cycle processes is mainly based on first-order kinetics (Manzoni $\mathcal{E}$ Porporato 2009), the soil $C$ turnover rate is commonly defined as the ratio of the $C$ flux (heterotrophic respiration, $R_{H}$ ) to the $C$ pool (SOC storage) (Chen et al. 2013). Accurate estimation of $R_{H}$ in situ is challenging, which impedes related studies on SOC turnover. The alternative approach is to collect field soils for laboratory incubation (Vesterdal et al. 2012; Li et al. 2018), but it is difficult to reproduce the real scenarios in the field (Feng et al. 2016). The ${ }^{13} \mathrm{C}$ natural abundance $\left(\delta^{13} \mathrm{C}\right)$ is an elegant tracer to evaluate the SOC turnover rate in situ, as the changes in $\delta^{13} \mathrm{C}$ with soil depth could reveal some important information on soil $\mathrm{C}$ turnover not evident based on elemental concentration analysis alone (Garten 2006; Diochon $\mathcal{E}$ Kellman 2008). Soil $\delta^{13} \mathrm{C}$ values generally tend to increase with depth in well-drained and undisturbed soils, concomitant with decreasing $\mathrm{C}$ concentrations (Balesdent et al. 1993; Wang et al. 2017). The slope of the linear regression $(\beta)$ between the log-transformed $C$ concentration and $\delta^{13} \mathrm{C}$ value in the soil profile has been proposed as a proxy for the SOC turnover rate in a number of studies (Acton et al. 2013; Gautam et al. 2017; Wang et al. 2018a).

In this study, we investigated the changes in $\mathrm{C}$ concentrations and $\delta^{13} \mathrm{C}$ values along soil profiles $(0-30 \mathrm{~cm})$ in an undisturbed old-growth forest and its two successional forests of natural restoration in subtropical China, which allowed us to examine the effects of forest succession on SOC turnover rates under the same regional climate. The three successional forests were a $P$. massoniana forest (PF; 60 years old), coniferous and broadleaved mixed forest (MF; 100 years old) and monsoon evergreen broadleaved forest (BF; > 400 years old). The SOC accumulation rate increased in the order of $\mathrm{PF}<\mathrm{MF}<\mathrm{BF}$ (Huang et al. 2011), although soil respiration was shown to increase with forest succession at the same site (Yan et al. 2009). However, how the SOC turnover rate changes with forest succession remains unclear. We hypothesized that the SOC turnover rate declines with forest succession, as the specific $R_{H}$ (the amount of respired- $C$ produced per unit microbial biomass C) decreases with the progressive maturity of the three forests (Huang et al. 2016).

\section{Methods}

Study sites

The present study was conducted at the Dinghushan Biosphere Reserve $\left(23^{\circ} 09^{\prime} 21^{\prime \prime}-23^{\circ} 11^{\prime} 30^{\prime \prime}\right.$ N, 112 $30^{\prime}$ $39^{\prime \prime}-112^{\circ} 33^{\prime} 41^{\prime \prime}$ E) in Guangdong Province, China (Fig. 1). The reserve covers an area of 1155 ha with elevations ranging from 14 to $1000 \mathrm{~m}$. The region is characterized by a typical subtropical monsoon climate. The mean annual temperature is $22.3^{\circ} \mathrm{C}$, with a mean monthly temperature of $13.9^{\circ} \mathrm{C}$ in January and $28.9^{\circ} \mathrm{C}$ in August. The mean annual precipitation is approximately $1927 \mathrm{~mm}$, of which nearly $80 \%$ falls in the hot-humid season (from April to September). The mean annual evaporation and relative humidity are $1115 \mathrm{~mm}$ and $78 \%$, respectively. The bedrocks are sandstone and shale belonging to the Devonian Period, and clay minerals are 


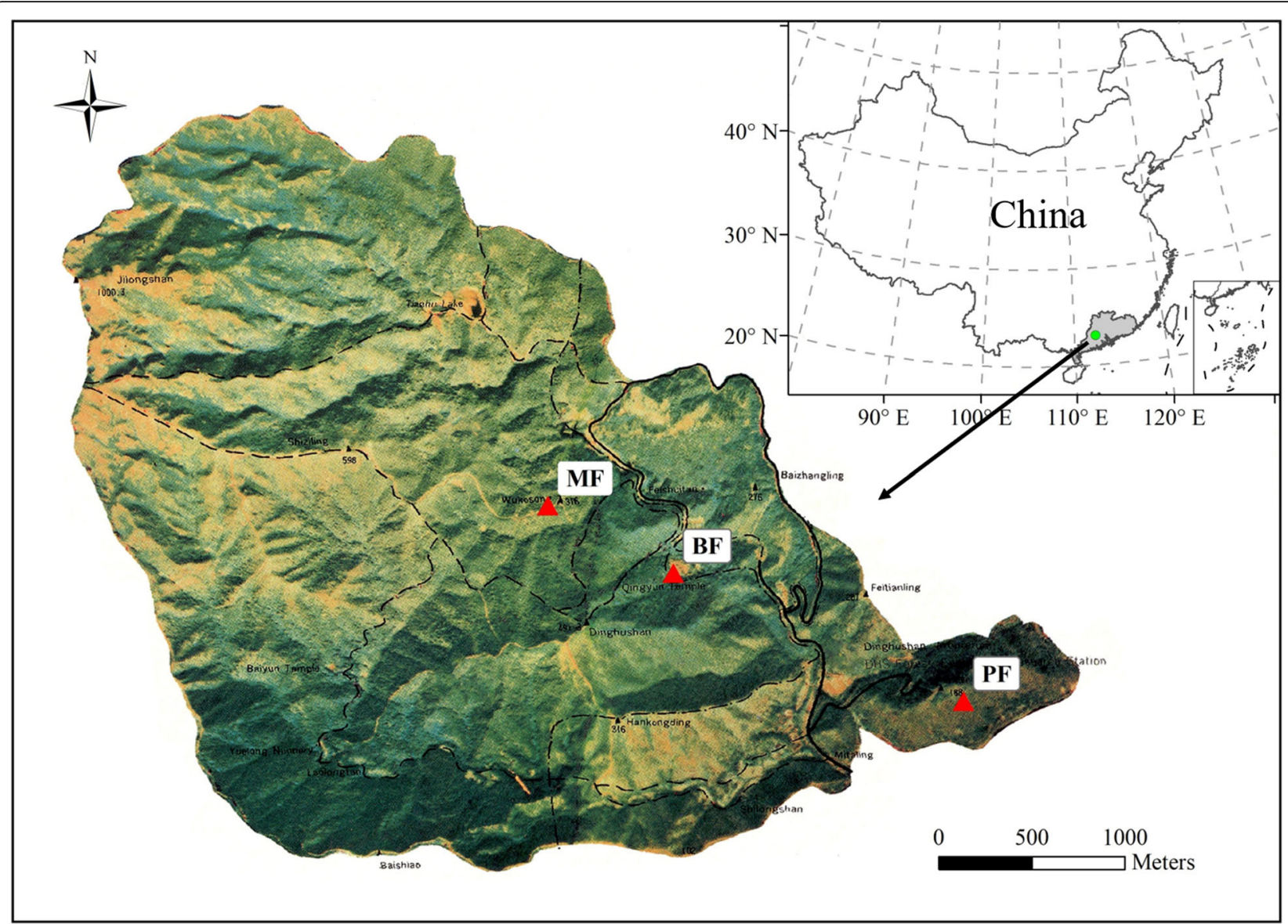

Fig. 1 The map of the study area and forest sites. PF, P. massoniana forest; MF, coniferous and broadleaved mixed forest; BF, monsoon evergreen broadleaved forest

mainly kaolinite and halloysite. Soils are classified in the Ultisol order and Udult suborder according to the USDA soil classification system (Buol et al. 2003).

There are three types of natural forest communities in this reserve: PF ( 60 years old), MF ( $\sim 100$ years old) and $\mathrm{BF}$ ( $>400$ years old). The BF is the climax community in this climatic region, and the PF and MF represent its early- and mid-successional stages, respectively. The dominant species in the BF included Aporusa yunnanensis, Blastus cochinchinensis, Castanopsis chinensis, Cryptocarya chinensis, Gironniera subaequalis and Schima superba. The PF was dominated by P. massoniana. In the MF, the dominant species included Castanopsis chinensis, Schima superba and P. massoniana; the biomass of $P$. massoniana continuously declined naturally, and the stand structure gradually converged to the BF.

\section{Field sample collection}

In October 2015, soil samples of $0-30 \mathrm{~cm}$ were collected from eight random plots $(10 \mathrm{~m} \times 10 \mathrm{~m})$ in each forest. In each plot, ten soil cores were randomly collected at three depths $(0-10,10-20$, and $20-30 \mathrm{~cm})$ and then pooled by depth. Each soil sample was divided into two parts: one part was sieved through a $2-\mathrm{mm}$ mesh while plant materials were removed, and stored at $4{ }^{\circ} \mathrm{C}$ for the determination of soil microbial biomass carbon (MBC) and other chemical analyses; and the other part was air-dried for the fractionation of water-stable aggregates.

\section{Water-stable aggregates}

Soil aggregates were divided into four aggregate size classes: large macroaggregates $(>2000 \mu \mathrm{m})$, small macroaggregates $(250-2000 \mu \mathrm{m})$, microaggregates $(53-250 \mu \mathrm{m})$, and silt $\mathcal{E}$ clay particles $(<53 \mu \mathrm{m})$. Aggregate separation was performed by a wet sieving approach adapted from Six et al. (1998).

The stability of the soil aggregate structure was expressed as the mean weight diameter (MWD) of all aggregate size fractions, and the parameter was calculated with the following equation (Kemper $\mathcal{E}$ Rosenau 1986):

$$
\mathrm{MWD}=\sum_{i=1}^{n} \overline{x_{i}} w_{i}
$$

where $\bar{x}_{i}$ is the mean diameter of each size fraction, $w_{i}$ is 
the proportion of the total sample weight of the corresponding size fraction, and $n$ is the number of all size fractions.

\section{Laboratory analyses}

The air-dried soil samples were measured for $\mathrm{pH}$ by a pH meter (PH510, Alalis, Shanghai, China) using a 1: 2.5 soil-water suspension. The soil water content (SWC) was measured by oven-drying $15 \mathrm{~g}$ of fresh soil sample at $105{ }^{\circ} \mathrm{C}$ for $24 \mathrm{~h}$. Soil MBC was determined by subjecting fresh soil samples to the chloroform fumigationextraction method (Vance et al. 1987). Soil readily oxidized organic carbon (ROC) was measured by $333 \mathrm{mM}$ $\mathrm{KMnO}_{4}$ oxidation-colorimetry (Blair et al. 1995). Soil available nitrogen (AN) was analyzed by alkali-diffusion method (Liu et al. 1996). The subsamples were analyzed for total organic $\mathrm{C}$ and total nitrogen (TN) contents and for $\mathrm{C}$ isotopic compositions by an isotope ratio mass spectrometer (IsoPrime 100, IsoPrime, Manchester, UK) connected to an elemental analyzer (Vario isotope cube, Elementar, Hanau, Germany). There was no treatment to remove inorganic $\mathrm{C}$ before elemental and isotopic analysis in the present study, since the soils were highly acidic (Table 2) and the inorganic $C$ contents were negligible.

The $\mathrm{C}$ isotope ratio $\left({ }^{13} \mathrm{C} /{ }^{12} \mathrm{C}\right)$ was expressed in $\delta$ notation (in \%o units):

$$
\delta=\left(\frac{R_{\text {sam }}}{R_{\text {std }}}-1\right) \times 1000
$$

where $R_{\text {sam }}$ is the ${ }^{13} \mathrm{C} /{ }^{12} \mathrm{C}$ ratio of the sample and $R_{\text {std }}$ is the ${ }^{13} \mathrm{C} /{ }^{12} \mathrm{C}$ ratio of the Vienna Pee Dee Belemnite standard (Coplen et al. 2006). Analysis of internal laboratory standards ensured that the precision of the measurements was $\pm 0.1 \%$ for $\delta^{13} \mathrm{C}$.

\section{Recalcitrance index}

In the present study, we defined the 'recalcitrance index' (RI) of soil organic matter as follows:

$$
\mathrm{RI}(\%)=\left(1-\frac{\mathrm{ROC}}{\mathrm{SOC}}\right) \times 100
$$

\section{Soil bulk density and SOC stock}

Soil bulk density (BD) was determined in parallel with field sampling. Undisturbed soil cores were taken from three random plots at three depths $(0-10,10-20$, and $20-30 \mathrm{~cm}$ ) in each forest using a stainless steel corer $(5.65 \mathrm{~cm}$ in diameter, $4 \mathrm{~cm}$ in depth). All soil cores were oven-dried at $105^{\circ} \mathrm{C}$ to a constant weight. Soil bulk density was calculated as the ratio of total dry weight to total soil volume.
SOC stock is the product of SOC concentration, layer thickness, and bulk density (Post et al. 2001). The SOC stock can be calculated as follows:

$$
\text { SOC stock }=\text { SOC concentration } \times H \times D
$$

where $H$ and $D$ are the soil layer thickness $(\mathrm{cm})$ and bulk density $\left(\mathrm{g} \cdot \mathrm{cm}^{-3}\right)$, respectively.

\section{$\beta$ value}

Enrichments in $\delta^{13} \mathrm{C}$ values with increasing depths in well-drained undisturbed soils concomitant with decreasing $\mathrm{C}$ concentrations have been broadly reported (Balesdent et al. 1993; Acton et al. 2013). The vertical changes in $\delta^{13} \mathrm{C}$ along soil profiles have been proven to be related to soil $\mathrm{C}$ turnover (Powers $\mathcal{E}$ Schlesinger 2002). The slope of a linear regression relating soil $\delta^{13} \mathrm{C}$ to the $\log$-transformed $\mathrm{C}$ concentration was used to describe the SOC turnover rate at different spatial scales (Gautam et al. 2017; Wang et al. 2018a):

$$
\delta^{13} \mathrm{C}=\beta \log (\mathrm{C})+b
$$

The slope of the regression $(\beta)$ is a proxy of the SOC turnover rate; a lower $\beta$ (steeper slope) is associated with a higher turnover rate, and $b$ is a constant.

\section{Data analyses}

All statistical analyses were conducted with SPSS statistical software (SPSS Statistics 20, IBM Corp.). Data were tested for homogeneity of variances and normal distribution before applying analysis of variance. One-way ANOVA was conducted to examine the differences in $\delta^{13} \mathrm{C}, \mathrm{SOC}, \mathrm{ROC}, \mathrm{RI}, \mathrm{MBC}, \mathrm{TN}, \mathrm{AN}, \mathrm{C} / \mathrm{N}, \mathrm{SWC}, \mathrm{pH}$, MWD, and BD of the upper 30-cm among different forests or different depths of same forest. Tukey's multiple comparison test was further conducted to separate differences among means. Ordinary least squares regression was used to examine the relationships between the $\beta$ value and soil properties. Statistical significance was determined at $p<0.05$ unless otherwise stated.

\section{Results}

SOC concentration and $\delta^{13} \mathrm{C}$

Both the SOC concentration and soil $\delta^{13} \mathrm{C}$ value showed significant differences among forests and soil depths $(p<0.05$; Table 1$)$. The SOC concentration at each depth in the BF was similar to that in the MF $(p>0.05)$ but was significantly higher than that in the PF $(p<0.05$; Table 1). The SOC concentrations significantly decreased with depth in all three forests $(p<0.05$; Table 1$)$. The soil $\delta^{13} \mathrm{C}$ value at each depth was lowest in the $\mathrm{BF}$, and there was no significant difference between the PF and MF $(p>0.05$; Table 1$)$. Contrary to the SOC 
Table 1 Concentrations and isotope abundance $\left(\delta^{13} \mathrm{C}\right)$ of soil organic carbon (SOC) in the upper $30 \mathrm{~cm}$ depth of different forests

\begin{tabular}{llll}
\hline Forest & Depth $(\mathbf{c m})$ & SOC $\left(\mathbf{g} \cdot \mathbf{k g}^{-\mathbf{1}}\right)$ & $\boldsymbol{\delta}^{\mathbf{1 3}} \mathbf{C}(\mathbf{\%})$ \\
\hline PF & $0-10$ & $18.56 \pm 0.84^{\mathrm{Ba}}$ & $-25.10 \pm 0.20^{\mathrm{Ac}}$ \\
& $10-20$ & $7.63 \pm 0.54^{\mathrm{Bb}}$ & $-22.46 \pm 0.35^{\mathrm{Ab}}$ \\
& $20-30$ & $5.37 \pm 0.39^{\mathrm{Cc}}$ & $-21.38 \pm 0.28^{\mathrm{Aa}}$ \\
MF & $0-10$ & $29.36 \pm 2.53^{\mathrm{Aa}}$ & $-25.77 \pm 0.27^{\mathrm{Ab}}$ \\
& $10-20$ & $14.62 \pm 0.82^{\mathrm{Ab}}$ & $-22.94 \pm 0.24^{\mathrm{Aa}}$ \\
& $20-30$ & $8.82 \pm 0.13^{\mathrm{BC}}$ & $-22.00 \pm 0.59^{\mathrm{Aa}}$ \\
BF & $0-10$ & $28.43 \pm 0.94^{\mathrm{Aa}}$ & $-27.31 \pm 0.17^{\mathrm{Bb}}$ \\
& $10-20$ & $15.89 \pm 0.56^{\mathrm{Ab}}$ & $-25.93 \pm 0.34^{\mathrm{Ba}}$ \\
& $20-30$ & $10.56 \pm 0.52^{\mathrm{Ac}}$ & $-25.04 \pm 0.35^{\mathrm{Ba}}$ \\
\hline
\end{tabular}

Values are the mean \pm standard error $(n=8)$. PF P. massoniana forest; MF coniferous and broadleaved mixed forest; $B F$ monsoon evergreen broadleaved forest. Different lowercase letters indicate significant differences among three depths in the same forest $(p<0.05)$. Different capital letters indicate significant differences among three forest types of the same depth $(p<0.05)$ concentration, the soil $\delta^{13} \mathrm{C}$ values significantly increased with depth in each forest $(p<0.05$; Table 1$)$.

\section{SOC stock and $\beta$ value}

As shown in Fig. 2, the SOC stock of the upper $30-\mathrm{cm}$ was lowest in the PF, and there was no significant difference between the MF and $\mathrm{BF}(p>0.05)$. The estimated $\beta$ value increased in the order of $\mathrm{PF}(-7.04 \pm 0.48)<\mathrm{MF}$ $(-6.66 \pm 0.42)<\mathrm{BF}(-5.22 \pm 0.41)$, and the value in the $\mathrm{BF}$ was significantly higher than that in the $\mathrm{PF}(p<0.05$; Fig. 2).

\section{Soil properties}

Significant differences were detected among different forests for most soil physicochemical properties $(p<$ 0.05; Table 2). The SOC concentration, ROC, RI, MBC, TN, SWC, and MWD were lowest in the PF, and there were no significant differences between the PF and MF

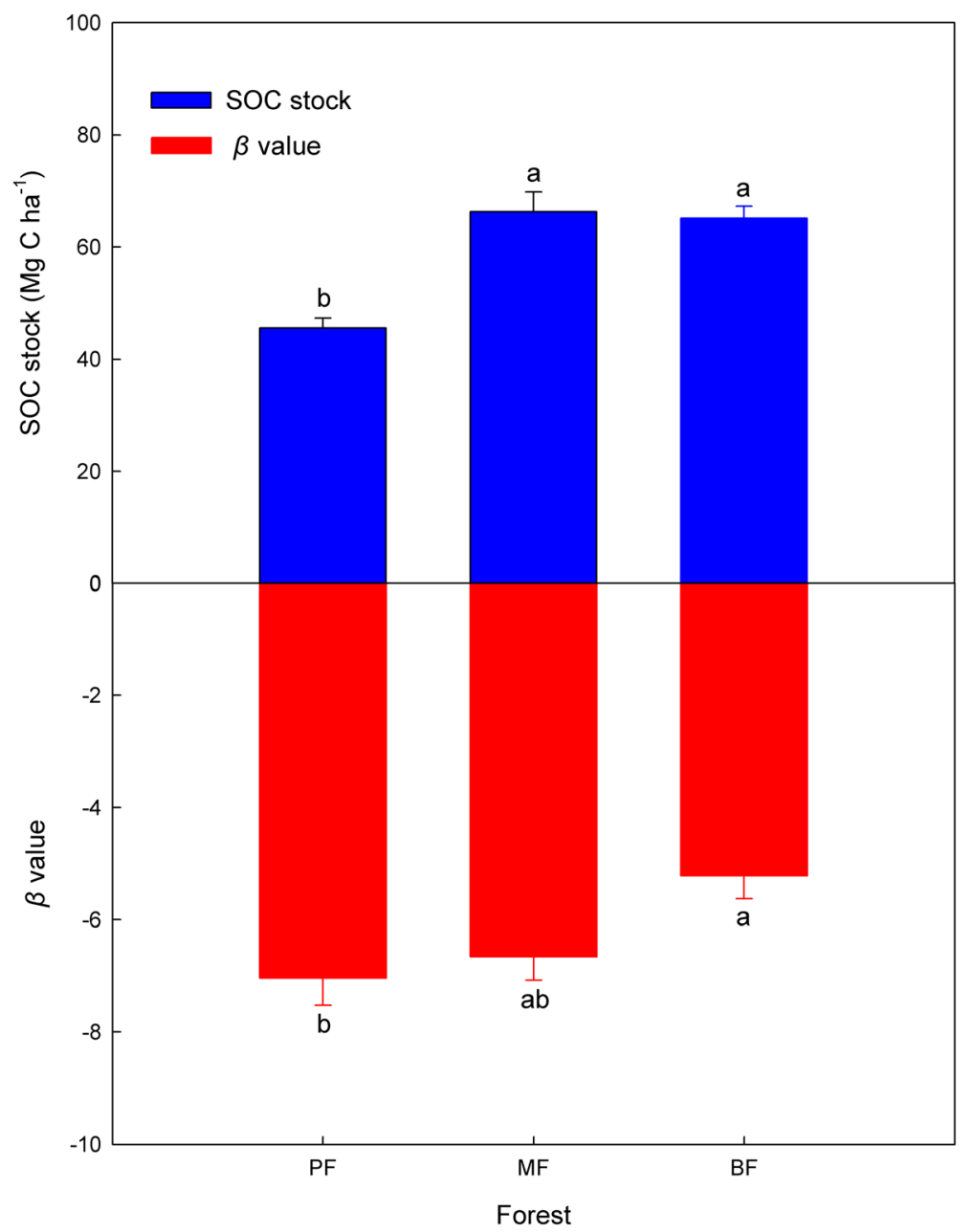

Fig. 2 Soil organic carbon (SOC) stocks and $\beta$ values in the upper 30-cm of soils in different forests. PF, P. massoniana forest; MF, coniferous and broadleaved mixed forest; $B F$, monsoon evergreen broadleaved forest. Different lowercase letters indicate significant differences among different forests $(p<0.05)$. The error bars indicate standard errors of the mean $(n=8)$ 
Table 2 Soil properties of the upper 30-cm in different forests

\begin{tabular}{llll}
\hline Forest & PF & MF & BF \\
\hline SOC $\left(\mathrm{g} \cdot \mathrm{kg}^{-1}\right)$ & $10.52 \pm 0.39^{\mathrm{b}}$ & $18.82 \pm 1.09^{\mathrm{a}}$ & $18.29 \pm 0.61^{\mathrm{a}}$ \\
ROC $\left(\mathrm{g} \cdot \mathrm{kg}^{-1}\right)$ & $3.29 \pm 0.14^{\mathrm{b}}$ & $5.37 \pm 0.41^{\mathrm{a}}$ & $4.83 \pm 0.25^{\mathrm{a}}$ \\
RI (\%) & $71.06 \pm 0.45^{\mathrm{b}}$ & $72.62 \pm 1.22^{\mathrm{ab}}$ & $75.10 \pm 0.51^{\mathrm{a}}$ \\
$\mathrm{MBC}\left(\mathrm{mg} \cdot \mathrm{kg}^{-1}\right)$ & $142.40 \pm 7.73^{\mathrm{b}}$ & $247.73 \pm 27.40^{\mathrm{a}}$ & $236.94 \pm 22.74^{\mathrm{a}}$ \\
TN $\left(\mathrm{g} \cdot \mathrm{kg}^{-1}\right)$ & $0.83 \pm 0.02^{\mathrm{b}}$ & $1.34 \pm 0.06^{\mathrm{a}}$ & $1.48 \pm 0.05^{\mathrm{a}}$ \\
AN $\left(\mathrm{mg}^{\mathrm{k}} \mathrm{kg}^{-1}\right)$ & $65.80 \pm 3.83^{\mathrm{c}}$ & $132.07 \pm 4.64^{\mathrm{b}}$ & $154.03 \pm 5.55^{\mathrm{a}}$ \\
C/N & $11.87 \pm 0.23^{\mathrm{b}}$ & $13.28 \pm 0.23^{\mathrm{a}}$ & $12.05 \pm 0.11^{\mathrm{b}}$ \\
SWC $(\%)$ & $15.86 \pm 0.52^{\mathrm{b}}$ & $24.06 \pm 0.97^{\mathrm{a}}$ & $25.10 \pm 0.58^{\mathrm{a}}$ \\
PH & $4.05 \pm 0.01^{\mathrm{a}}$ & $3.95 \pm 0.03^{\mathrm{b}}$ & $3.91 \pm 0.02^{\mathrm{b}}$ \\
MWD (mm) & $172.96 \pm 19.02^{\mathrm{b}}$ & $321.30 \pm 17.79^{\mathrm{a}}$ & $256.39 \pm 22.52^{\mathrm{a}}$ \\
BD $\left(\mathrm{g} \cdot \mathrm{cm}^{-3}\right)$ & $1.45 \pm 0.06^{\mathrm{a}}$ & $1.23 \pm 0.03^{\mathrm{b}}$ & $1.21 \pm 0.04^{\mathrm{b}}$ \\
\hline
\end{tabular}

Values are the mean \pm standard error $(n=8$; for the $\mathrm{BD}, n=3)$. PF $P$. massoniana forest; $M F$ coniferous and broadleaved mixed forest; $B F$ monsoon evergreen broadleaved forest; $S O C$ soil organic carbon; $R O C$ readily oxidized organic carbon; $R I$ recalcitrance index; $M B C$ microbial biomass carbon; $T N$ total nitrogen; $A N$ available nitrogen; $C / N$ the ratio of carbon to nitrogen; $S W C$ soil water content; $M W D$ mean weight diameter of soil aggregates; $B D$ bulk density. Different lowercase letters indicate significant differences among different forests $(p<0.05)$

$(p>0.05$; Table 2). Soil AN significantly increased in the order of $\mathrm{PF}<\mathrm{MF}<\mathrm{BF}(p<0.05$; Table 2$)$. The $\mathrm{C} / \mathrm{N}$ ratio of soil was highest in the MF, and there was no significant difference between the PF and $\mathrm{BF}(p>0.05$; Table $2)$. The soil $\mathrm{pH}$ and $\mathrm{BD}$ in the BF were similar to those in the MF $(p>0.05)$ but were significantly lower than those in the PF $(p<0.05$; Table 2$)$.

The relationships between the $\beta$ value and soil properties The results of regression analyses showed that the $\beta$ value of soil profile was positively correlated with RI $\left(R^{2}=0.38, p<0.01\right.$; Fig. 3a), TN $\left(R^{2}=0.27, p<0.05\right.$; Fig. $3 \mathrm{~b})$, and $\mathrm{AN}\left(R^{2}=0.26, p<0.05\right.$; Fig. $\left.3 \mathrm{c}\right)$ but negatively correlated with $\mathrm{pH}\left(R^{2}=0.34, p<0.01\right.$; Fig. $\left.3 \mathrm{~d}\right)$. However, the relationships between the $\beta$ value and SOC, MBC, C/N, MWD and SWC were not significant $(p>$ 0.05; Figs. 3e-i).

\section{Discussion}

\section{SOC storage and turnover following forest succession}

Forest age is an important factor affecting SOC storage (Marin-Spiotta \& Sharma 2013). Our results revealed that the surface $(0-30 \mathrm{~cm})$ SOC stock in the 100 -yearold MF reached the level of the primary forest, whereas the SOC stock in the 60-year-old PF was still at a low level. However, this result does not mean that forest soil $\mathrm{C}$ stocks will peak within 100 years. Increasing evidence has confirmed that old-growth forests can continue to accumulate $\mathrm{C}$ in soils for centuries or longer (Zhou et al. 2006a; Luyssaert et al. 2008), even as net primary productivity declines (Xiong et al. 2020a). It is worth noting that the mechanisms underlying SOC accumulation in old-growth forests are distinct from those in young forests (Zhou et al. 2006b). In early-successional forests, the increase in the soil $\mathrm{C}$ pool mainly results from the continuous increase in biomass, and the gained $\mathrm{C}$ is concentrated in the topsoil layer (Xiong et al. 2020a). As the forest matures, SOC accumulation turns to the deeper soil layers, owing to the low $\mathrm{C} / \mathrm{N}$ ratio of litter and rhizospheric material, and the moist soil environment. The former facilitates a high proportion of organic $\mathrm{C}$ yield input to the soil during decomposition, and the latter contributes to the migration of organic $\mathrm{C}$ along the whole soil profile (Tefs \& Gleixner 2012; Xiong et al. 2020a).

Our results showed the enrichment of soil $\delta^{13} \mathrm{C}$ with depth in all three forests, concomitant with decreasing $\mathrm{C}$ concentrations (Table 1). This result is consistent with earlier observations in well-drained forest soils (Powers E Schlesinger 2002; Acton et al. 2013; Wang et al. 2018a). The increasing trend in $\delta^{13} \mathrm{C}$ with soil depth might be attributed to two main processes: mixing of different $\mathrm{C}$ sources and soil $\mathrm{C}$ decomposition (Diochon $\mathcal{E}$ Kellman 2008; Acton et al. 2013). The Suess effect describes the isotopic depletion of atmospheric $\mathrm{CO}_{2}$ as a result of the combustion of ${ }^{13} \mathrm{C}$-depleted fossil fuels and biomass burning (Friedli et al. 1986), which could have caused the increasing trend in $\delta^{13} \mathrm{C}$ with soil depth (more ${ }^{13} \mathrm{C}$-enriched older $\mathrm{SOC}$ in the deep and more ${ }^{13} \mathrm{C}$-depleted recent SOC at the surface) (Diochon $\mathcal{E}$ Kellman 2008). However, Torn et al. (2002) showed that the $\mathrm{C}$ isotopic signatures of a modern soil profile (collected in 1997) are similar to its 100-year-old archive soil (collected sometime between 1895 and 1903) from the same site, indicating that the change of soil $\delta^{13} \mathrm{C}$ with depth is not due to the isotopic depletion of atmospheric $\mathrm{CO}_{2}$. A few studies proposed that roots are generally more ${ }^{13} \mathrm{C}$-enriched than leaves or branches from the same plant, and so the soil $\delta^{13} \mathrm{C}$ value at the surface may be lower than that in the deeper soil (Powers \& Schlesinger 2002). However, we did not find significant differences in $\delta^{13} \mathrm{C}$ values between roots and above-ground litter at the present site by 10 years of observation (Xiong et al. 2020b). The existing evidence implies that the contribution of the mixing of different $C$ sources to the vertical $\delta^{13} \mathrm{C}$ enrichment along soil profiles should be small in the present study.

The relationship between $\beta$ value and SOC turnover rate has been tested in a number of studies (Gautam et al. 2017; Wang et al. 2018a; Xiong et al. 2020b), as a lower $\beta$ value implies a higher turnover rate. The results showed that the $\beta$ value ranged from -7.04 to -5.22 in the present study (Fig. 2), which is in accordance with the measurements in Brazilian tropical forests (Telles et al. 2003) but lower than other observations at similar latitudes (Chiang et al. 2004; Chen et al. 2005; Richards 


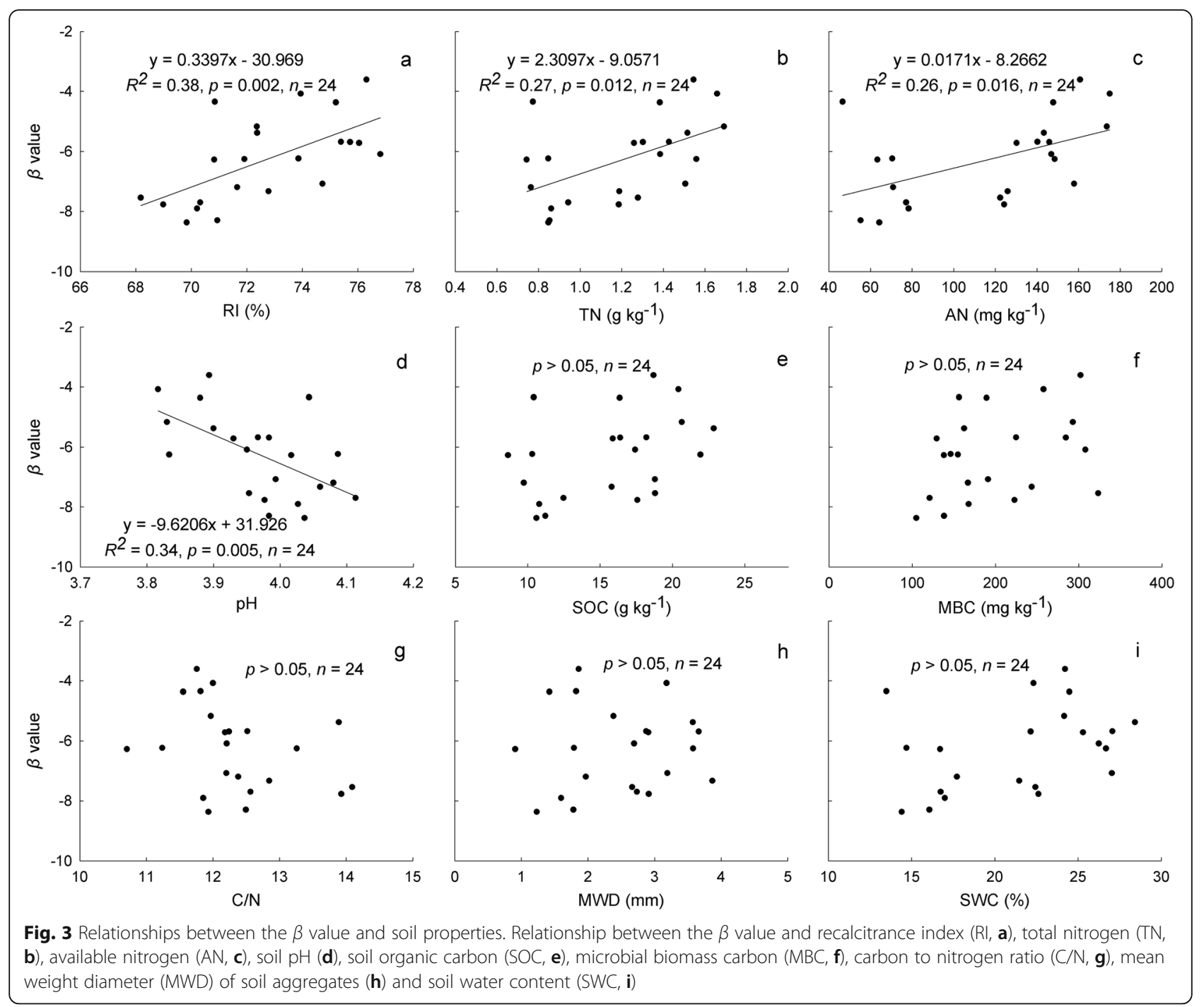

et al. 2007), the discrepancy probably was attributed to the deeper soils $(0-100 \mathrm{~cm})$ considered in the above studies.

Our results also showed that the $\beta$ value increased with the progressive maturity of the three forests, indicating that the SOC turnover rate decreased during forest succession. This is consistent with a previous study that measured soil respiration components by a trenching method in the three forests (Huang et al. 2016). Although higher soil $\mathrm{R}_{\mathrm{H}}$ was measured in the latesuccessional forest, this could be mainly caused by higher $C$ input and SOC stock, whereas the specific $R_{H}$ declined with forest succession, and soil microbes became more efficient in conserving $\mathrm{C}$ resources with forest succession (Huang et al. 2016; Wang et al. 2019). Our finding is supported by another related study (Wang et al. 2018b). Based on the data consolidation of 1087 forest plots in eastern China, the researchers reported that the SOC turnover time was positively correlated with forest age. Reduced SOC turnover, combined with continuous high $\mathrm{C}$ input (Xiong et al. 2020a), sustains the soil $\mathrm{C}$ sinks in old-growth forests.

\section{Influences of soil properties on the SOC turnover rate}

Our results showed that soil physical and chemical properties differed in the different forests, but the differences in most soil properties were slight between the mid- and late-successional stages (Table 2). Soil properties are considered to play an important role in regulating the dynamics of SOC turnover across different scales (Torn et al. 1997; Xu et al. 2016). In the present study, the correlations between the $\beta$ value and soil physicochemical variables were analyzed (Fig. 3), and the results showed that soil RI, nitrogen status and $\mathrm{pH}$ were the main controls that regulated the SOC turnover rates.

Our results showed that the $\beta$ value was positively correlated with soil RI (Fig. 3a), which is in accordance with the conventional opinion that reduced SOC turnover is 
accompanied by enhanced soil chemical recalcitrance (Sollins et al. 1996). For a long time, the formation of recalcitrant components (e.g., humus, lignin, and long chain $\mathrm{n}$-alkanes) has been considered the major pathway for SOC stabilization (Derenne $\mathcal{E}$ Largeau 2001; Piccolo 2001). According to the concept of 'selective preservation', soil organic matter is composed of both labile and relatively recalcitrant compounds, the latter being used by microorganisms only when the former are exhausted (von Lützow et al. 2006). Despite recent analytical and experimental advances demonstrating that intrinsic molecular characteristics alone do not control SOC stability: environmental and biological controls act jointly (Kleber 2010; Schmidt et al. 2011), we cannot ignore the chemical nature of organic matter in specific studies. Lavallee et al. (2019) reported that pyrogenic $\mathrm{C}$ decomposition is controlled by a different mechanism than biogenic C, and the latter has a shorter residence time. Nisar $\mathcal{E}$ Bendi (2020) conducted a field management experiment and found that the addition of compost, in addition to leading to $\mathrm{C}$ build-up, improved $\mathrm{C}$ stabilization by imparting recalcitrance to SOC. In the three successional forests, the proportion of labile constituents in litter increased with forest maturity (Huang et al. 2011), and this change contributed to the formation of recalcitrant components in the soil, which was shown in other studies (Cotrufo et al. 2013; Xu et al. 2014).

In the present study, we observed that the rates of SOC turnover decreased with increasing soil nitrogen status (Figs. $3 \mathrm{~b}-\mathrm{c}$ ). This finding is supported by previous studies in the three successional forests. Based on a seven-year nitrogen manipulation experiment, $\mathrm{Lu}$ et al. (2013) reported that nitrogen addition increased soil C accumulation in the upper soils by decreasing dissolved organic C leaching. Mo et al. (2008) found that high nitrogen addition $\left(15 \mathrm{~g} \mathrm{~N} \cdot \mathrm{m}^{-2} \cdot \mathrm{year}^{-1}\right)$ could reduce soil respiration accompanied with a decrease in soil microbial activities. As the forest matures, the soil nitrogen status increases, and the combination of increasing soil $\mathrm{C}$ storage and decreasing soil respiration leads to a reduction in SOC turnover rates. Nitrogen addition has been found to impede organic matter decomposition and thus stimulate $\mathrm{C}$ sequestration across different ecosystems (Reay et al. 2008). A meta-analysis by Janssens et al. (2010) revealed that, averaged over 36 nitrogen manipulation studies in forest ecosystems, soil $R_{H}$ declined by $15 \%$ when nitrogen was added. Another metaanalysis showed that nitrogen fertilization decreased the soil $\mathrm{C}$ turnover rate in agroecosystems ( $\mathrm{Lu}$ et al. 2011). The positive coupling relationship between soil $\mathrm{C}$ storage and nitrogen storage has also been reported in numerous studies (Batjes 1996; Carter et al. 1997). In the light of our results and previous studies, we speculate that the increase in global nitrogen deposition may mitigate the rise of atmospheric $\mathrm{CO}_{2}$ to some extent by increasing the retention time of $\mathrm{C}$ in soils.

Our results showed that the $\beta$ value was inversely associated with soil $\mathrm{pH}$ (Fig. 3d), indicating that the SOC turnover rate decreased with increasing soil acidity. This finding is in line with previous studies in cropland and grassland (Kemmitt et al. 2006; Leifeld et al. 2013). The regulation of soil $\mathrm{pH}$ on SOC turnover rate may be explained by the changes in substrate availability and microbial activity. A low $\mathrm{pH}$ could reduce substrate availability through the combination operation of physical and chemical protection, such as, decreasing surface charge density and degree of dissociation, and increasing co-precipitation with aluminum (Leifeld et al. 2013). Soil microbial growth is retarded in an acidic environment, followed by the reduction of soil respiration (Malik et al. 2018). Increased soil acidity could reduce the intrinsic activity of the microbial community by a number of direct and indirect routes including: (1) reducing the amount of substrate entering the soil, (2) inhibiting certain members of the community (e.g., nitrifiers), and (3) increasing aluminum in the soil, which induces physiological toxicity (Kemmitt et al. 2006). Our previous studies are in favor of the above inferences. Wu et al. (2016) showed that prolonged acid rain facilitated organic $\mathrm{C}$ accumulation in the topsoil, following the inhibition of litter decomposition, soil microbial biomass, enzyme activities, and soil respiration. Furthermore, the depressed effect on soil respiration showed an increasing trend with the progressive acidification in soils (Liang et al. 2013). On the other hand, the proportion of recalcitrant components was higher in soils with lower $\mathrm{pH}$, which also favors the retention and accumulation of organic C in mineral soils (Wu et al. 2020).

The results of this study showed that soil MBC had no direct effect on the $\beta$ value (Fig. 3f), probably because SOC turnover is not affected by soil microbial biomass but is governed by microbial community composition and C use efficiency (Geyer et al. 2016). Unexpectedly, we did not detect direct evidence for the impact of soil moisture on the SOC turnover rate (Fig. 3i), whereas it is widely accepted as a critical regulator of SOC dynamics (Falloon et al. 2011; Green et al. 2019). Soil water content has great temporal variability ( $\mathrm{Hu}$ et al. 2013), and the results of a single sampling may not be able to present the true soil moisture status. In the present study, soil MWD did not show a linear trend with forest development (Table 2). The formation of soil aggregate structure is controlled by the complex interplay of multiple factors, such as organic input, microbial activity, and soil chemical properties (Bronick \& Lal 2005; Regelink et al. 2015), and the relationship between soil aggregates and the SOC turnover rate needs further exploration. We also recognized the importance of climatic factors in the process of 
SOC turnover; unfortunately, there is a lack of long-term meteorological data in individual forests. Generally, climatic factors are considered the primary controls in regulating $\beta$ values (Garten et al. 2000; Acton et al. 2013). However, in a particular climate area, soil properties may play a more important role than climatic factors in SOC turnover dynamics (Doetterl et al. 2015; Wang et al. 2017). Yang et al. (2015) also reported that edaphic rather than climatic variables were better determinants of $\delta^{13} \mathrm{C}$ enrichment from vegetation to soil on the Tibetan Plateau.

\section{Conclusions}

Our results showed that the $\beta$ value in the upper $30-\mathrm{cm}$ of soils increased with forest maturity, which was mainly regulated by the soil recalcitrance index, nitrogen status, and soil $\mathrm{pH}$. These findings demonstrate that SOC has lower turnover rates in old-growth forests, which helps to elucidate the mechanism underlying $C$ sequestration in old-growth forest soils. The present study emphasizes the important value of old-growth forests as a global C sink, and provides guidance in predicting the responses of forest soil $\mathrm{C}$ pools to global change.

\section{Abbreviations}

AN: Available nitrogen; BD: Bulk density; BF: Monsoon evergreen broadleaved forest; C: Carbon; C/N: Carbon to nitrogen ratio; MBC: Microbial biomass carbon; MF: Coniferous and broadleaved mixed forest; MWD: Mean weight diameter; PF: P. massoniana forest; $R_{H}$ : Heterotrophic respiration; Rl: Recalcitrance index; ROC: Readily oxidized organic carbon; SOC: Soil organic carbon; SWC: Soil water content; TN: Total nitrogen; $\delta^{13} \mathrm{C}:{ }^{13} \mathrm{C}$ natural abundance
}

\section{Acknowledgements}

Not applicable.

\section{Authors' contributions}

DZ conceived and designed the study; XX analyzed and interpreted the data, and wrote the primary draft; $J \mathrm{~L}, \mathrm{GZ}$, and $\mathrm{QD}$ revised the draft; $\mathrm{HZ}$ and XX did the measurements; GC and ZM collected the samples. All authors read and approved the final manuscript.

\section{Funding}

The research was jointly supported by the China Postdoctoral Science Foundation (No. 2020 M682951), the National Natural Science Foundation of China (No. NSFC41773088), and the Key Research Program of the Chinese Academy of Sciences (No. QYZDJ-SSW-DQC003).

\section{Availability of data and materials}

The datasets used during the current study are available from the corresponding author on reasonable request.

\section{Declarations}

Ethics approval and consent to participate

Not applicable.

\section{Consent for publication \\ Not applicable.}

\section{Competing interests}

The authors declare that they have no competing interests.

\section{Author details}

Key Laboratory of Vegetation Restoration and Management of Degraded Ecosystem, South China Botanical Garden, Chinese Academy of Sciences, Guangzhou 510650, China. ${ }^{2}$ Center for Plant Ecology, Core Botanical Gardens, Chinese Academy of Sciences, Guangzhou 510650, China. ${ }^{3}$ School of Applied Meteorology, Nanjing University of Information Science \& Technology, Nanjing 210044, China.

Received: 21 February 2021 Accepted: 29 April 2021

Published online: 08 September 2021

\section{References}

Acton P, Fox J, Campbell E, Rowe H, Wilkinson M (2013) Carbon isotopes for estimating soil decomposition and physical mixing in well-drained forest soils. J Geophys Res-Biogeo 118(4):1532-1545. https://doi.org/10.1002/2013 jg002400

Balesdent J, Girardin C, Mariotti A (1993) Site-related delta-C-13 of tree leaves and soil organic matter in a temperate forest. Ecology 74(6):1713-1721. https:// doi.org/10.2307/1939930

Batjes NH (1996) Total carbon and nitrogen in the soils of the world. Eur J Soil Sci 47(1):151-163. https://doi.org/10.1111/ejss.12114_2

Blair GJ, Lefroy RDB, Lise L (1995) Soil carbon fractions based on their degree of oxidation and the development of a carbon management index for agricultural systems. Aust J Agric Res 46(7):1459-1466. https://doi.org/10.1 $071 / \operatorname{ar} 9951459$

Bronick CJ, Lal R (2005) Soil structure and management: a review. Geoderma 124(1-2):3-22. https://doi.org/10.1016/j.geoderma.2004.03.005

Buol SW, Southard RJ, Graham RC, McDaniel PA (2003) Soil genesis and classification, fifth edn. lowa State Press, Ames, pp 339-347

Carter MR, Angers DA, Gregorich EG, Bolinder MA (1997) Organic carbon and nitrogen stocks and storage profiles in cool, humid soils of eastern Canada. Can J Soil Sci 77(2):205-210. https://doi.org/10.4141/S96-111

Chen Q, Shen C, Sun Y, Peng S, Yi W, Li Z, Jiang M (2005) Spatial and temporal distribution of carbon isotopes in soil organic matter at the Dinghushan biosphere reserve, South China. Plant Soil 273(1-2):115-128. https://doi.org/1 0.1007/s11104-004-7245-y

Chen S, Huang Y, Zou J, Shi Y (2013) Mean residence time of global topsoil organic carbon depends on temperature, precipitation and soil nitrogen. Glob Planet Chang 100:99-108. https://doi.org/10.1016/j.gloplacha.2012.10. 006

Chiang PN, Wang MK, Chiu CY, King HB, Hwong JL (2004) Changes in the grassland-forest boundary at ta-ta-chia long term ecological research (LTER) site detected by stable isotope ratios of soil organic matter. Chemosphere 54(2):217-224. https://doi.org/10.1016/j.chemosphere.2003.07.005

Clements FE (1916) Plant succession: an analysis of the development of vegetation. Carnegie Institution of Washington, Washington, DC. https://doi. org/10.5962/bhl.title.56234

Coplen TB, Brand WA, Gehre M, Groning M, Meijer HAJ, Toman B, Verkouteren RM (2006) New guidelines for delta C-13 measurements. Anal Chem 78(7): 2439-2441. https://doi.org/10.1021/ac052027c

Cotrufo MF, Wallenstein MD, Boot CM, Denef K, Paul E (2013) The microbial efficiency-matrix stabilization (MEMS) framework integrates plant litter decomposition with soil organic matter stabilization: do labile plant inputs form stable soil organic matter? Glob Chang Biol 19(4):988-995. https://doi. org/10.1111/gcb.12113

Derenne S, Largeau C (2001) A review of some important families of refractory macromolecules: composition, origin, and fate in soils and sediments. Soil Sci 166(11):833-847. https://doi.org/10.1097/00010694-200111000-00008

Diochon A, Kellman L (2008) Natural abundance measurements of (13) C indicate increased deep soil carbon mineralization after forest disturbance. Geophys Res Lett 35(14):L14402. https://doi.org/10.1029/2008gl034795

Doetterl S, Stevens A, Six J, Merckx R, Van Oost K, Casanova Pinto M, CasanovaKatny A, Munoz C, Boudin M, Zagal Venegas E, Boeckx P (2015) Soil carbon storage controlled by interactions between geochemistry and climate. Nat Geosci 8(10):780-783. https://doi.org/10.1038/ngeo2516

Falloon P, Jones CD, Ades M, Paul K (2011) Direct soil moisture controls of future global soil carbon changes: an important source of uncertainty. Global Biogeochem Cy 25(3):GB3010. https://doi.org/10.1029/2010gb003938

Feng W, Shi Z, Jiang J, Xia J, Liang J, Zhou J, Luo Y (2016) Methodological uncertainty in estimating carbon turnover times of soil fractions. Soil Biol Biochem 100:118-124. https://doi.org/10.1016/j.soilbio.2016.06.003 
Friedli H, Lotscher H, Oeschger H, Siegenthaler U, Stauffer B (1986) Ice core record of the $\mathrm{C}-12 / \mathrm{C}-13$ ratio of atmospheric $\mathrm{CO}_{2}$ in the past 2 centuries. Nature 324(6094):237-238. https://doi.org/10.1038/324237a0

Garten CT (2006) Relationships among forest soil C isotopic composition, partitioning, and turnover times. Can J For Res 36(9):2157-2167. https://doi. org/10.1139/x06-115

Garten CT, Cooper LW, Post WM, Hanson PJ (2000) Climate controls on forest soil C isotope ratios in the southern Appalachian Mountains. Ecology 81(4):11081119. https://doi.org/10.2307/177182

Gautam MK, Lee KS, Song BY, Bong YS (2017) Site related delta C-13 of vegetation and soil organic carbon in a cool temperate region. Plant Soil 418(1-2):293-306. https://doi.org/10.1007/s11104-017-3284-z

Geyer KM, Kyker-Snowman E, Grandy AS, Frey SD (2016) Microbial carbon use efficiency: accounting for population, community, and ecosystem-scale controls over the fate of metabolized organic matter. Biogeochemistry 127(23):173-188. https://doi.org/10.1007/s10533-016-0191-y

Goulden ML, McMillan AMS, Winston GC, Rocha AV, Manies KL, Harden JW, Bond-Lamberty BP (2011) Patterns of NPP, GPP, respiration, and NEP during boreal forest succession. Glob Chang Biol 17(2):855-871. https://doi.org/1 0.1111/j.1365-2486.2010.02274.x

Gray AN, Whittier TR, Harmon ME (2016) Carbon stocks and accumulation rates in Pacific northwest forests: role of stand age, plant community, and productivity. Ecosphere 7(1):e01224. https://doi.org/10.1002/ecs2.1224

Green JK, Seneviratne SI, Berg AM, Findell KL, Hagemann S, Lawrence DM, Gentine P (2019) Large influence of soil moisture on long-term terrestrial carbon uptake. Nature 565(7740):476-479. https://doi.org/10.1038/s41586-01 8-0848-x

Hu W, Shao MA, Hou MT, She DL, Si BC (2013) Mean soil water content estimation using measurements from time stable locations of adjacent or distant areas. J Hydrol 497:234-243. https://doi.org/10.1016/j.jhydrol.2013.05. 046

Huang W, Han T, Liu J, Wang G, Zhou G (2016) Changes in soil respiration components and their specific respiration along three successional forests in the subtropics. Funct Ecol 30(8):1466-1474. https://doi.org/10.1111/1365-243 5.12624

Huang Y, Li Y, Xiao Y, Wenigmann KO, Zhou G, Zhang D, Wenigmann M, Tang X, Liu J (2011) Controls of litter quality on the carbon sink in soils through partitioning the products of decomposing litter in a forest succession series in South China. Forest Ecol Manag 261(7):1170-1177. https://doi.org/10.1016/ j.foreco.2010.12.030

Janssens IA, Dieleman W, Luyssaert S, Subke JA, Reichstein M, Ceulemans R, Ciais P, Dolman AJ, Grace J, Matteucci G, Papale D, Piao SL, Schulze ED, Tang J, Law BE (2010) Reduction of forest soil respiration in response to nitrogen deposition. Nat Geosci 3(5):315-322. https://doi.org/10.1038/ngeo844

Jarvis PG (1989) Atmospheric carbon dioxide and forests. Philos T R Soc B 324(1223):369-392. https://doi.org/10.1098/rstb.1989.0053

Kemmitt S, Wright D, Goulding KWT, Jones DL (2006) pH regulation of carbon and nitrogen dynamics in two agricultural soils. Soil Biol Biochem 38(5):898911. https://doi.org/10.1016/j.soilbio.2005.08.006

Kemper WD, Rosenau RC (1986) Aggregate stability and size distribution. In: Klute A (ed) Methods of soil analysis. ASA and SSSA, Madison, pp 425-442

Kleber M (2010) What is recalcitrant soil organic matter? Environ Chem 7(4):320332. https://doi.org/10.1071/EN10006

Lavallee JM, Conant RT, Haddix ML, Follett RF, Bird MI, Paul EA (2019) Selective preservation of pyrogenic carbon across soil organic matter fractions and its influence on calculations of carbon mean residence times. Geoderma 354: 113866. https://doi.org/10.1016/j.geoderma.2019.07.024

Leifeld J, Bassin S, Conen F, Hajdas I, Egli M, Fuhrer J (2013) Control of soil pH on turnover of belowground organic matter in subalpine grassland. Biogeochemistry 112(1-3):59-69. https://doi.org/10.1007/s10533-011-9689-5

Li L, Zhu-Barker X, Ye R, Doane TA, Horwath WR (2018) Soil microbial biomass size and soil carbon influence the priming effect from carbon inputs depending on nitrogen availability. Soil Biol Biochem 119:41-49. https://doi. org/10.1016/j.soilbio.2018.01.003

Li Y, Yang F, Ou Y, Zhang D, Liu J, Chu G, Zhang Y, Otieno D, Zhou G (2013) Changes in forest soil properties in different successional stages in lower tropical China. PLoS One 8(11):e81359. https://doi.org/10.1371/journal.pone. 0081359

Liang G, Liu X, Chen X, Qiu Q, Zhang D, Chu G, Liu J, Liu S, Zhou G (2013) Response of soil respiration to acid rain in forests of different maturity in southern China. PLoS One 8(4):e62207. https://doi.org/10.1371/journal.pone. 0062207

Liu G, Jiang N, Zhang L, Liu Z (1996) Soil physical and chemical analysis, and description of soil profiles. Standards Press of China, Beijing, pp 33-37

Liu Y, Yu G, Wang Q, Zhang Y (2014) How temperature, precipitation and stand age control the biomass carbon density of global mature forests. Glob Ecol Biogeogr 23(3):323-333. https://doi.org/10.1111/geb.12113

Lu M, Zhou X, Luo Y, Yang Y, Fang C, Chen J, Li B (2011) Minor stimulation of soil carbon storage by nitrogen addition: a meta-analysis. Agric Ecosyst Environ 140(1-2):234-244. https://doi.org/10.1016/j.agee.2010.12.010

Lu X, Gilliam FS, Yu G, Li L, Mao Q, Chen H, Mo J (2013) Long-term nitrogen addition decreases carbon leaching in a nitrogen-rich forest ecosystem. Biogeosciences 10(6):3931-3941. https://doi.org/10.5194/bg-10-3931-2013

Lu X, Mao Q, Mo J, Gilliam FS, Zhou G, Luo Y, Zhang W, Huang J (2015) Divergent responses of soil buffering capacity to long-term $\mathrm{N}$ deposition in three typical tropical forests with different land-use history. Environ Sci Technol 49(7):4072-4080. https://doi.org/10.1021/es5047233

Luyssaert S, Schulze ED, Boerner A, Knohl A, Hessenmoeller D, Law BE, Ciais P, Grace J (2008) Old-growth forests as global carbon sinks. Nature 455(7210): 213-215. https://doi.org/10.1038/nature07276

Malik AA, Puissant J, Buckeridge KM, Goodall T, Jehmlich N, Chowdhury S, Gweon HS, Peyton JM, Mason KE, van Agtmaal M, Blaud A, Clark IM, Whitaker J, Pywell RF, Ostle N, Gleixner G, Griffiths RI (2018) Land use driven change in soil pH affects microbial carbon cycling processes. Nat Commun 9(1):3591. https://doi.org/10.1038/s41467-018-05980-1

Manzoni S, Porporato A (2009) Soil carbon and nitrogen mineralization: theory and models across scales. Soil Biol Biochem 41(7):1355-1379. https://doi. org/10.1016/j.soilbio.2009.02.031

Marin-Spiotta E, Sharma S (2013) Carbon storage in successional and plantation forest soils: a tropical analysis. Glob Ecol Biogeogr 22(1):105-117. https://doi. org/10.1111/j.1466-8238.2012.00788.x

Mo J, Zhang W, Zhu W, Gundersen P, Fang Y, Li D, Wang H (2008) Nitrogen addition reduces soil respiration in a mature tropical forest in southern China. Glob Chang Biol 14(2):403-412. https://doi.org/10.1111/j.1365-2486.2 007.01503.x

Nisar S, Benbi DK (2020) Stabilization of organic C in an indo-Gangetic alluvial soil under long-term manure and compost management in a rice-wheat system. Carbon Manag 11(6):533-547. https://doi.org/10.1080/17583004.202 0.1824483

Nyawira SS, Nabel JEMS, Brovkin V, Pongratz J (2017) Input-driven versus turnover-driven controls of simulated changes in soil carbon due to land-use change. Environ Res Lett 12(8):084015. https://doi.org/10.1088/1748-9326/aa $7 \mathrm{ca} 9$

Odum EP (1969) Strategy of ecosystem development. Science 164(3877):262-270. https://doi.org/10.1126/science.164.3877.262

Paul EA (2016) The nature and dynamics of soil organic matter: plant inputs, microbial transformations, and organic matter stabilization. Soil Biol Biochem 98:109-126. https://doi.org/10.1016/j.soilbio.2016.04.001

Piccolo A (2001) The supramolecular structure of humic substances. Soil Sci 166(11):810-832. https://doi.org/10.1097/00010694-200111000-00007

Post WM, Izaurralde RC, Mann LK, Bliss N (2001) Monitoring and verifying changes of organic carbon in soil. Clim Chang 51(1):73-99. https://doi.org/1 0.1023/a:1017514802028

Powers JS, Schlesinger WH (2002) Geographic and vertical patterns of stable carbon isotopes in tropical rain forest soils of Costa Rica. Geoderma 109(1-2): 141-160. https://doi.org/10.1016/s0016-7061(02)00148-9

Reay DS, Dentener F, Smith P, Grance J, Feely RA (2008) Global nitrogen deposition and carbon sinks. Nat Geosci 1(7):430-437. https://doi.org/10.103 $8 /$ ngeo230

Regelink IC, Stoof CR, Rousseva S, Weng L, Lair GJ, Kram P, Nikolaidis NP, Kercheva M, Banwart S, Comans RNJ (2015) Linkages between aggregate formation, porosity and soil chemical properties. Geoderma 247:24-37. https://doi.org/10.1016/j.geoderma.2015.01.022

Ren C, Liu W, Zhao F, Zhong Z, Deng J, Han X, Yang G, Feng Y, Ren G (2019) Soil bacterial and fungal diversity and compositions respond differently to forest development. Catena 181:104071. https://doi.org/10.1016/j.catena.2019.104 071

Richards AE, Dalal RC, Schmidt S (2007) Soil carbon turnover and sequestration in native subtropical tree plantations. Soil Biol Biochem 39(8):2078-2090. https://doi.org/10.1016/j.soilbio.2007.03.012 
Sánchez-Reyes UJ, Nino-Maldonado S, Barrientos-Lozano L, Trevino-Carreon J, Melendez-Jaramillo E, Sandoval-Becerra FM, Jones RW (2020) Structural changes of vegetation and its association with microclimate in a successional gradient of low thorn forest in northeastern Mexico. Plant Ecol 222(1):65-80. https://doi.org/10.1007/s11258-020-01088-z

Schmidt MWI, Torn MS, Abiven S, Dittmar T, Guggenberger G, Janssens IA, Kleber M, Kögel-Knabner I, Lehmann J, Manning DAC, Nannipieri P, Rasse DP, Weiner S, Trumbore SE (2011) Persistence of soil organic matter as an ecosystem property. Nature 478(7367):49-56. https://doi.org/10.1038/nature1 0386

Six J, Elliott ET, Paustian K, Doran JW (1998) Aggregation and soil organic matter accumulation in cultivated and native grassland soils. Soil Sci Soc Am J 62(5): 1367-1377. https://doi.org/10.2136/sssaj1998.03615995006200050032x

Sokołowska J, Józefowska A, Woźnica K, Zaleski T (2020) Succession from meadow to mature forest: impacts on soil biological, chemical and physical properties_evidence from the Pieniny Mountains, Poland. Catena 189: 104503. https://doi.org/10.1016/j.catena.2020.104503

Sollins P, Homann P, Caldwell BA (1996) Stabilization and destabilization of soil organic matter: mechanisms and controls. Geoderma 74(1-2):65-105. https:// doi.org/10.1016/S0016-7061(96)00036-5

Tefs C, Gleixner G (2012) Importance of root derived carbon for soil organic matter storage in a temperate old-growth beech forest - evidence from C, N and C-14 content. Forest Ecol Manag 263:131-137. https://doi.org/10.1016/j. foreco.2011.09.010

Telles EDC, de Camargo PB, Martinelli LA, Trumbore SE, da Costa ES, Santos J, Higuchi N, Oliveira RC (2003) Influence of soil texture on carbon dynamics and storage potential in tropical forest soils of Amazonia. Global Biogeochem Cy 17(2):1040. https://doi.org/10.1029/2002GB001953

Torn MS, Lapenis AG, Timofeev A, Fischer ML, Babikov BV, Harden JW (2002) Organic carbon and carbon isotopes in modern and 100-year-old-soil archives of the Russian steppe. Glob Chang Biol 8(10):941-953. https://doi. org/10.1046/j.1365-2486.2002.00477.x

Torn MS, Trumbore SE, Chadwick OA, Vitousek PM, Hendricks DM (1997) Mineral control of soil organic carbon storage and turnover. Nature 389(6647):170173. https://doi.org/10.1038/38260

Vance ED, Brookes PC, Jenkinson DS (1987) An extraction method for measuring soil microbial biomass C. Soil Biol Biochem 19(6):703-707. https://doi.org/10.1 016/0038-0717(87)90052-6

Vesterdal L, Elberling B, Christiansen JR, Callesen I, Schmidt IK (2012) Soil respiration and rates of soil carbon turnover differ among six common European tree species. Forest Ecol Manag 264:185-196. https://doi.org/10.101 6/j.foreco.2011.10.009

Von Lützow M, Kögel-Knabner I, Ekschmitt K, Matzner E, Guggenberger G, Marschner B, Flessa H (2006) Stabilization of organic matter in temperate soils: mechanisms and their relevance under different soil conditions - a review. Eur J Soil Sci 57(4):426-445. https://doi.org/10.1111/j.1365-2389.2006. 00809.x

Wang C, Houlton BZ, Liu D, Hou J, Cheng W, Bai E (2018a) Stable isotopic constraints on global soil organic carbon turnover. Biogeosciences 15(4):987995. https://doi.org/10.5194/bg-15-987-2018

Wang C, Wei H, Liu D, Luo W, Hou J, Cheng W, Han X, Bai E (2017) Depth profiles of soil carbon isotopes along a semi-arid grassland transect in northern China. Plant Soil 417(1-2):43-52. https://doi.org/10.1007/s11104-017-3233-x

Wang G, Huang W, Mayes MA, Liu X, Zhang D, Zhang Q, Han T, Zhou G (2019) Soil moisture drives microbial controls on carbon decomposition in two subtropical forests. Soil Biol Biochem 130:185-194. https://doi.org/10.1016/j. soilbio.2018.12.017

Wang J, Sun J, Xia J, He N, Li M, Niu S (2018b) Soil and vegetation carbon turnover times from tropical to boreal forests. Funct Ecol 32(1):71-82. https:// doi.org/10.1111/1365-2435.12914

Wu J, Deng Q, Hui D, Xiong X, Zhang H, Zhao M, Wang X, Hu M, Su Y, Zhang H, Chu G, Zhang D (2020) Reduced lignin decomposition and enhanced soil organic carbon stability by acid rain: evidence from C -13 isotope and C-13 NMR analyses. Forests 11(11):1191. https://doi.org/10.3390/f11111191

Wu J, Liang G, Hui D, Deng Q, Xiong X, Qiu Q, Liu J, Chu G, Zhou G, Zhang D (2016) Prolonged acid rain facilitates soil organic carbon accumulation in a mature forest in southern China. Sci Total Environ 544:94-102. https://doi. org/10.1016/j.scitotenv.2015.11.025

Xiong X, Zhang H, Deng Q, Hui D, Chu G, Meng Z, Zhou G, Zhang D (2020b) Soil organic carbon turnover following forest restoration in South China: evidence from stable carbon isotopes. Forest Ecol Manag 462:117988. https://doi.org/10.1016/j.foreco.2020.117988

Xiong X, Zhou G, Zhang D (2020a) Soil organic carbon accumulation modes between pioneer and old-growth forest ecosystems. J Appl Ecol 57(12):24192428. https://doi.org/10.1111/1365-2664.13747

Xu X, Schimel JP, Thornton PE, Song X, Yuan F, Goswami S (2014) Substrate and environmental controls on microbial assimilation of soil organic carbon: a framework for earth system models. Ecol Lett 17(5):547-555. https://doi.org/1 0.1111/ele.12254

Xu X, Shi Z, Li D, Rey A, Ruan H, Craine JM, Liang J, Zhou J, Luo Y (2016) Soil properties control decomposition of soil organic carbon: results from dataassimilation analysis. Geoderma 262:235-242. https://doi.org/10.1016/j. geoderma.2015.08.038

Yan J, Zhang D, Zhou G, Liu J (2009) Soil respiration associated with forest succession in subtropical forests in Dinghushan biosphere reserve. Soil Biol Biochem 41(5):991-999. https://doi.org/10.1016/j.soilbio.2008.12.018

Yang Y, Ji C, Chen L, Ding J, Cheng X, Robinson D (2015) Edaphic rather than climatic controls over ${ }^{13} \mathrm{C}$ enrichment between soil and vegetation in alpine grasslands on the Tibetan plateau. Funct Ecol 29(6):839-848. https://doi.org/1 $0.1111 / 1365-2435.12393$

Zhou G, Liu S, Li Z, Zhang D, Tang X, Zhou C, Yan J, Mo J (2006a) Old-growth forests can accumulate carbon in soils. Science 314(5804):1417-1417. https:// doi.org/10.1126/science.1130168

Zhou G, Xu S, Ciais P, Manzoni S, Fang J, Yu G, Tang X, Zhou P, Wang W, Yan J, Wang G, Ma K, Li S, Du S, Han S, Ma Y, Zhang D, Liu J, Liu S, Chu G, Zhang Q, Li Y, Huang W, Ren H, Lu X, Chen X (2019) Climate and litter C/N ratio constrain soil organic carbon accumulation. Natl Sci Rev 6(4):746-757. https://doi.org/10.1093/nsr/nwz045

Zhou G, Zhou C, Liu S, Tang X, Ouyang X, Zhang D, Liu S, Liu J, Yan J, Zhou C, Luo Y, Guan L, Liu Y (2006b) Belowground carbon balance and carbon accumulation rate in the successional series of monsoon evergreen broadleaved forest. Sci China Earth Sci 49(3):311-321. https://doi.org/10.1007/s1143 0-006-0311-y

\section{Submit your manuscript to a SpringerOpen ${ }^{\odot}$ journal and benefit from:}

- Convenient online submission

- Rigorous peer review

- Open access: articles freely available online

High visibility within the field

- Retaining the copyright to your article

Submit your next manuscript at $>$ springeropen.com 